[J. Appl. Glycosci., Vol. 47, No. 2, p. 155-161 (2000)]

\title{
Isolation and Characterization of Arabinogalactan-protein from the Fruit of Lycium chinense Mill
}

\author{
Xiaoming Qin, Ryo Yamauchi, Koichi Aizawa,' Takahiro Inakuma ${ }^{1}$ and Koji Kato* \\ The United Graduate School of Agricultural Science, Gifu University, Science of Biological Resources \\ (Gifu University) (1-1, Yanagido, Gifu 501-1193, Japan) \\ ${ }^{1}$ Research Institute, Kagome Co., Ltd. (17, Nishitoyama, Nishinasuno, Nasu, Tochigi 329-2762, Japan)
}

\begin{abstract}
Two kinds of arabinogalactan-protein (Cp-1-C and -D) were obtained from the fruit of Lycium chinense Mill. In $\mathrm{Cp}-1-\mathrm{C}$, the carbohydrate was composed of arabinose and galactose at a ratio of 3:1, and $O$-glycosidically linked to both the serine and threonine residues of protein. Its molecular weight was 42,000 . In Cp-1-D, the ratio of arabinose to galactose was $1: 1$, and the $O$-glycosidical junction between the carbohydrate and protein was composed of serine residue. The molecular weight was 23,000 . From the results of structural characterization, both $\mathrm{Cp}-1-\mathrm{C}$ and $-\mathrm{D}$ were assigned to type II arabinogalactan-protein (AGP), where a $(1 \rightarrow 6)$ linkage of galactose occurred mainly at the branching point in the case of Cp-1-C and mainly at the linear part in Cp-1-D.
\end{abstract}

The fruit of Lycium chinense Mill (gouqizi in Chinese, and kuko in Japanese) has been used as a herb and has been known as a somewhat famous ingredient since ancient times in China as well as Japan. Recently, a water extract of the fruit was found to have a range of pharmacological functions such as the enhancement of immune response, ${ }^{1-3)}$ the inhibition of apoptosis induced by dextroamphetamine, ${ }^{4)}$ and the restoration to genetic wounding, ${ }^{5)}$ and the polysaccharide in the extract was estimated to be an active component. ${ }^{6}$ We previously reported that the polysaccharide extracted with water from the fruit was separated mainly to three fractions (Cp-1,-2 and -3) by DEAEcellulose column $\left(\mathrm{HCO}_{3}^{-}\right.$form), two of which (Cp-1 and -2) were presumed to be composed mainly of the arabinogalactan-protein (AGP). ${ }^{7}$ In this paper, we report the further purification of $\mathrm{Cp}$ 1 and characterization of the resultant carbohydrateprotein.

\section{MATERIAL AND METHODS}

Material. Commercially available fruit of $L y$ -

${ }^{*}$ Corresponding author. cium chinense Mill, which was harvested and airdried in the Ningxia province of China in 1996, was extracted with water at $4^{\circ} \mathrm{C}$, and the extract submitted to DEAE-cellulose column chromatography $\left(\mathrm{HCO}_{3}{ }^{-}\right.$form). The polysaccharide fraction (Cp1) eluted with $0.1 \mathrm{M} \mathrm{NH}_{4} \mathrm{HCO}_{3}$ was used for the experiment. The yield of $\mathrm{Cp}-1$ was $0.54 \%$ of the dried fruit.

General methods. Total sugar was determined by the phenol-sulfuric acid method, ${ }^{8)}$ and galacturonic acid by the carbazole-sulfuric acid method. ${ }^{9)}$ Protein content was estimated by a modified Lowry method. ${ }^{10)} \mathrm{A}$ glycosyl residue (neutral sugar) of the polysaccharide was analyzed as alditol acetate after acid hydrolysis. ${ }^{11)}$ Gas-liquid chromatography (GLC) was carried out on a Shimadzu GC-18A apparatus equipped with a flame ionization detector. A capillary column of CBP-10-M25$025(0.2 \mathrm{~mm} \times 25 \mathrm{~m})$ was used and operated at $220^{\circ} \mathrm{C}$ with a gas flow rate of $60 \mathrm{~mL} / \mathrm{min}$ of nitrogen. Peak areas were measured with a Shimadzu Chromatocorder-21. Gas chromatography-mass spectrometer (GC-MS) was conducted with a Shimadzu GC-MS QP-1000 apparatus equipped with a CBP-1-M25-025 capillary column $(0.2 \mathrm{~mm} \times 25$ m) programmed from 160 to $230^{\circ} \mathrm{C}$ at $3^{\circ} \mathrm{C} / \mathrm{min}$, 
and the spectra were recorded at an ionizing potential of $70 \mathrm{eV}$. Infrared (IR) spectra were recorded with a Perkin Elmer 2000 FT-IR infrared spectrometer system. The specific rotations were measured with a Horiba polarimeter SEPA-300. Amino acid residues of the protein were determined after acid hydrolysis $\left(6 \mathrm{M} \mathrm{HCl}, 110^{\circ} \mathrm{C}, 16 \mathrm{~h}, \mathrm{~N}_{2}\right.$ atmosphere) using a Millipore LC-module 1 analysis system equipped with a column of PICO-TAG $(3.9 \times 150 \mathrm{~mm}$, Waters Co.). Liquid chromatography at about 7.4 Mpa (HPLC) was performed in a JASCO apparatus (880-PU pump, 860-CO column oven, and 830-RI detector). For the estimation of molecular weight of the polysaccharide, a Shodex OHpak KB-805 $(8 \times 300 \mathrm{~mm})$ column was used and operated at $45^{\circ} \mathrm{C}$ with a solvent flow rate of $0.1 \mathrm{M} \mathrm{NH}_{4} \mathrm{HCO}_{3}$ at $0.8 \mathrm{~mL} / \mathrm{min}$. The peak areas were estimated with a System Instrument SIC Chromatocorder $11 .{ }^{1} \mathrm{H}-$ and ${ }^{13} \mathrm{C}-\mathrm{NMR}$ spectra were recorded at $399.956\left({ }^{1} \mathrm{H}\right)$ and $100.578 \mathrm{MHz}$ $\left({ }^{13} \mathrm{C}\right)$ with a Varian FT-NMR unity inova 400. Chemical shifts are given in $\delta$ values.

\section{RESULTS AND DISCUSSION}

\section{Isolation of arabinogalactan-protein (AGP) from $\mathrm{Cp}-1$.}

A sample $(30 \mathrm{mg})$ of $\mathrm{Cp}-1$ was submitted to DEAE-cellulose column $\left(\mathrm{B}_{4} \mathrm{O}_{7}{ }^{2-}\right.$ form, $\left.2.6 \times 50 \mathrm{~cm}\right)$ chromatography being monitored by the phenolsulfuric acid method. The column was eluted with water and then stepwise with 0.02, 0.04, 0.06, 0.08 $M$ and saturated $\mathrm{Na}_{2} \mathrm{~B}_{4} \mathrm{O}_{7}$ at a flow rate of $30 \mathrm{~mL} /$ h. Four kinds of polysaccharide fraction (Cp-1-A, -B, -C and -D) were obtained (Fig.1). Each fraction was dialyzed against running water and lyophilized. Some of the properties of each fraction are shown in Table 1. A glycosyl residue analysis of the fractions suggested that $\mathrm{Cp}-1-\mathrm{A}$ should be mainly composed of arabinoxylan (ara: $\mathrm{xyl}=1: 1$ ) and Cp-1-B mainly araban. Cp-1-C (and -D) was composed of arabinose and galactose at a ratio of 3:1 (and 1:1) together with a small amount of fucose, xylose, mannose, glucose and galacturonic acid. The last two fractions were considered to be the arabinogalactan-protein (AGP) anticipated in the previous paper since they also con-

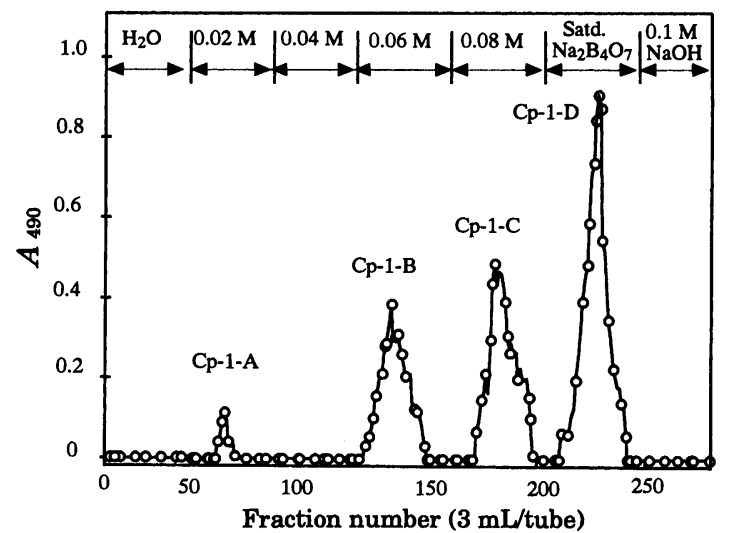

Fig. 1. Elution profile of $\mathrm{Cp}-1$ on a DEAE-Cellulose column.

$\mathrm{Cp}-1$ was dissolved in distilled water and loaded on a DEAE-Cellulose column $\left(2.6 \times 50 \mathrm{~cm}, \mathrm{~B}_{4} \mathrm{O}_{7}{ }^{2-}\right.$ form $)$. After being washed with distilled water, the column was eluted with $0.02-0.08 \mathrm{M}$ sodium borate, saturated sodium borate and $0.1 \mathrm{M}$ sodium hydroxide successively. Fractions were collected and analyzed for total sugar.

Table 1. Some properties of $\mathrm{Cp}-1-\mathrm{A},-\mathrm{B},-\mathrm{C}$ and -D.

\begin{tabular}{lcrrr}
\hline & Cp-1-A & Cp-1-B & Cp-1-C & Cp-1-D \\
\hline Yield $^{a}$ & 1.8 & 24.8 & 31.1 & 42.3 \\
{$[\alpha]_{\mathrm{D}}\left(c=0.2, \mathrm{H}_{2} \mathrm{O}\right)$} & - & +14.5 & -5.0 & -12.0 \\
Mw $\times 10^{4}$ & 1.0 & 1.1 & 4.2 & 2.3 \\
Protein (\%) & 1.0 & 5.4 & 5.5 & 3.7 \\
Total sugar (\%) & 87.8 & 89.4 & 92.4 & 90.7 \\
GalA (\%) & 4.3 & 2.7 & 7.1 & 8.6 \\
Ara & 28.0 & 70.7 & 66.0 & 41.4 \\
Gal & 5.13 & 8.4 & 22.7 & 42.7 \\
Fuc & 3.7 & 7.7 & 4.4 & 2.5 \\
Xyl & 23.0 & 4.1 & 0.8 & 2.0 \\
Man & 8.3 & 1.9 & 1.5 & 2.5 \\
Glc & 8.4 & 1.9 & 0.9 & 1.0 \\
\hline
\end{tabular}

${ }^{a}$ Percentage to dry-weight basis of $\mathrm{Cp}-1$.

tained a protein at 5.5 and $3.7 \%$, respectively. Many workers have perceived that AGPs have never failed to be accompanied by a small amount of various neutral and acidic sugars. ${ }^{12-14)}$ When considering it, such monosaccharide could be a component of Cp-1-C (and -D), though its location in the polysaccharide could not be clarified. It is well-known that two kinds of arabinogalactan and AGP, type I (arabino-4-galactan) and II (arabino -3,6-galactan), have been isolated from various plants, ${ }^{15,16)}$ and in most of them the ratio of arabi- 
nose to galactose is ca. $1: 2$. In both samples, however, the ratio of arabinose to galactose was more than one (ara/gal=3 in $\mathrm{Cp}-1-\mathrm{C}$, and 1 in $-\mathrm{D})$. Such AGP has been found in turnip (ara/gal= $3.2)^{17)}$ and the root of radish $(=1.4),{ }^{13)}$ which have been assigned to type II.

\section{Linkage analysis of $C p-1-C$ and $-D$ by methyl- ation.}

Five milligrams of $\mathrm{Cp}-1-\mathrm{C}$ (and -D) was methylated by a modified Hakomori procedure. ${ }^{18)}$ The product was confirmed to show no absorption for the hydroxyl group in its IR spectrum, and it hydrolyzed with $90 \%$ formic acid and then with 0.25 $M$ sulfuric acid. The partially methylated sugar thus obtained was converted to alditol acetate for GLC and GC-MS analyses. GLC gave some peaks as shown in Fig. 2, and six of them were identified by their retention times and mass spectrum as shown in Fig. 3. These are summarized in Table 2. The ratio of methylated arabinose to galactose was $2.72(=66.7 / 24.5)$ in $\mathrm{Cp}-1-\mathrm{C}$ and $1.11(=49.4 /$ 44.6) in Cp-1-D. This is coincident with the result of the glycosyl residue analysis (Table 1). In both samples, almost half of the arabinose was found to occur at the non-reducing terminal unit in furanose form and the remainder was linked through $O-3$ or $O-5$, the ratio of $O-3$ and $O-5$ linkage being ca. $1: 1$. Moreover the ratio of 3-O-substituted galactose to total galactose was almost the same in both samples $[22 \%(=5.5 / 24.5)$ in $\mathrm{Cp}-1-\mathrm{C}$, and $21 \%(=$ 9.4/44.6) in Cp-1-D]. It is interesting that the linkage of galactose through $O-6$ occurs at the same rate but at a different kind of galactosyl residue in $\mathrm{Cp}-1-\mathrm{C}$ and -D. That is to say, it occurred mainly at 3-O-substituted galactose in $\mathrm{Cp}-1-\mathrm{C}$ to yield 3,6di- $O$-substituted galactose, consequently giving the branching domain of the polysaccharide. In the case of Cp-1-D, it occurred mainly at the galactose located in the non-reducing terminal yielding 6-Osubstituted galactose, consequently giving the linear domain of the polysaccharide. AGP in Cp-1-C, therefore, should be a polysaccharide branched more than that in $\mathrm{Cp}-1-\mathrm{D}$. It could be concluded that the fraction of $\mathrm{Cp}-1$ contained two kinds of AGP and that both of them should be classified to type-II AGP.

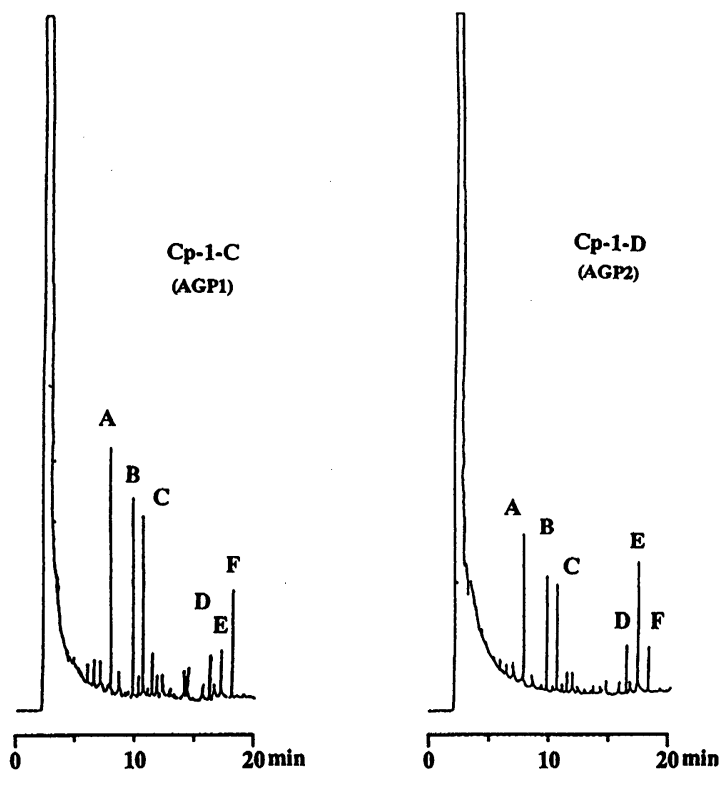

Fig. 2. Gas chromatograms of partially methylated alditol acetates from $\mathrm{Cp}-1-\mathrm{C}$ and $-\mathrm{D}$.

A: 1,4-di- $O$-acetyl-2,3,5-tri- $O$-methyl-arabinitol, B: 1 , 3,4-tri- $O$-acetyl-2,5-di- $O$-methyl-arabinitol, C: 1,4,5-tri$O$-acetyl-2,3-di- $O$-methyl-arabinitol, D:1,3,5-tri- $O$-acetyl2,4,6-tri-O-methyl-galactitol, E: 1,5,6-tri- $O$-acetyl-2,3,4tri- $O$-methyl-galactitol, F: 1,3,5,6-tetra- $O$-acetyl-2,4-di- $O$ methyl-galactose.

Table 2. Methylation analysis of $\mathrm{Cp}-1-\mathrm{C}$ and $\mathrm{Cp}-1-\mathrm{D}$.

\begin{tabular}{|c|c|c|c|}
\hline \multicolumn{2}{|c|}{ Alditol acetate of linkage } & \multirow{2}{*}{$\frac{\text { Cp-1-C }}{34.3}$} & \multirow{2}{*}{$\frac{C p-1-D}{27.8}$} \\
\hline 2,3,5-- $\mathrm{Me}_{3}$-L-Ara & L-Araf- $(1 \rightarrow$ & & \\
\hline 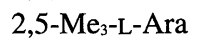 & $\rightarrow 3)$-L-Araf-(1 $\rightarrow$ & 17.8 & 11.6 \\
\hline 2,3- $\mathrm{Me}_{2}-\mathrm{L}-\mathrm{Ara}$ & $\rightarrow 5)$-L-Araf-( $(1 \rightarrow$ & 14.6 & 10.0 \\
\hline Total & & 66.7 & 49.4 \\
\hline 2,4,6--Me $-\mathrm{D}-\mathrm{Gal}$ & $\rightarrow 3$ )-D-Galp-(1 $\rightarrow$ & 5.5 & 9.4 \\
\hline 2,3,4-Me $-\mathrm{M}-\mathrm{D}-\mathrm{Gal}$ & $\rightarrow 6)$-D-Galp-(1 $\rightarrow$ & 5.8 & 25.5 \\
\hline 2,4-Me $2-\mathrm{D}-\mathrm{Gal}$ & $\rightarrow 3,6)$-D-Galp-(1 $\rightarrow$ & 13.2 & 9.7 \\
\hline Total & & 24.5 & 44.6 \\
\hline
\end{tabular}

\section{${ }^{1} \mathrm{H}$ - and ${ }^{13} \mathrm{C}-\mathrm{NMR}$ analysis of $\mathrm{Cp}-1-\mathrm{C}$ (and -D).}

The spectra were recorded at room temperature in $\mathrm{D}_{2} \mathrm{O}$. Water soluble TMS (sodium 3-trimethylsilylpropionate-2,2,3,3- $d_{4}$ ) was used as the internal standard. In the ${ }^{1} \mathrm{H}-\mathrm{NMR}$ spectrum, signals at 5.27 (and 5.26) and 5.10 (and 5.09) were easily recognized from other signals, and each was assigned to terminal and 3-(and 5-) $\mathrm{O}$-substituted arabinofuran- 

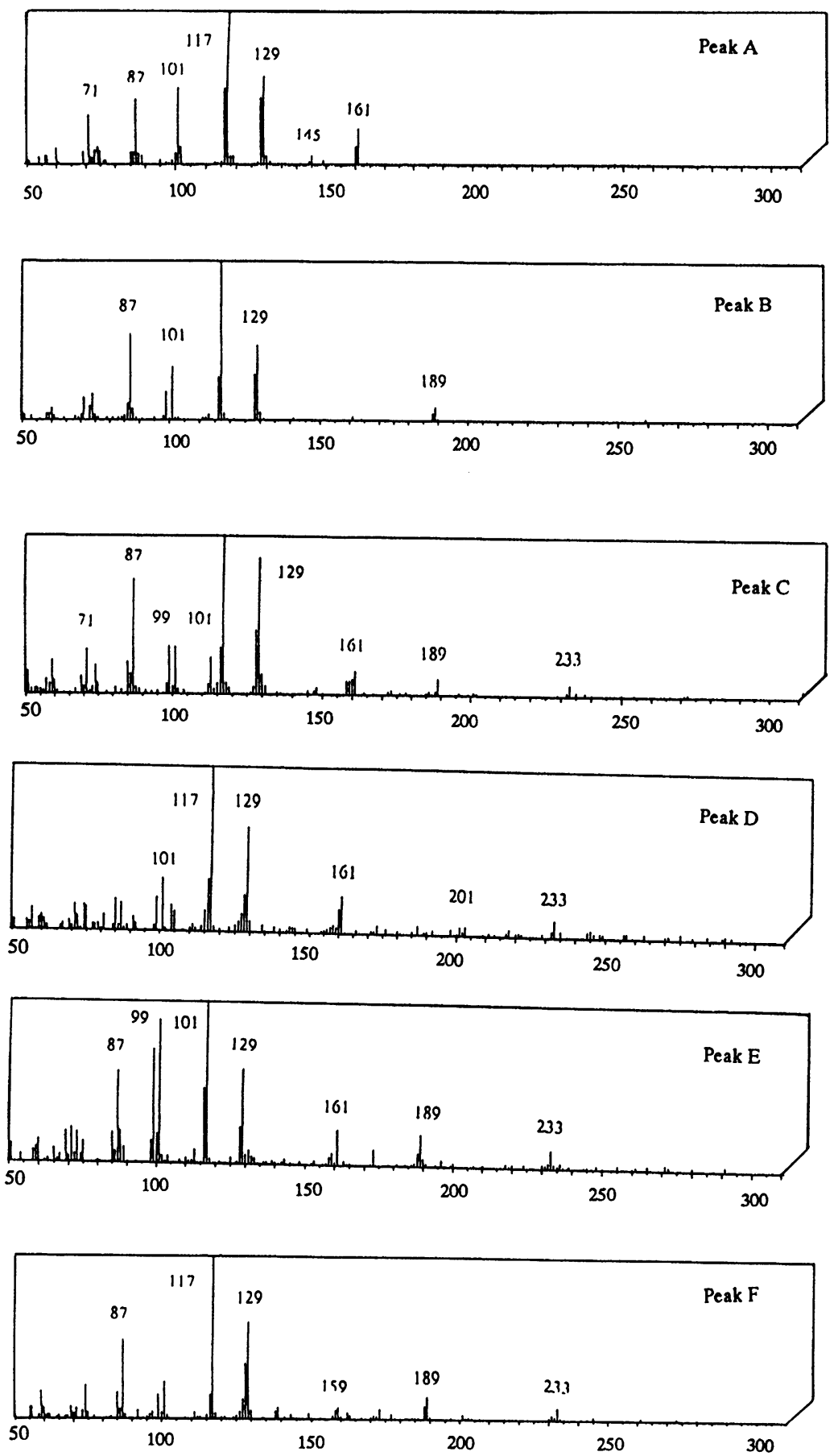

Fig. 3. Mass spectrum of each peak of $\mathrm{Cp}-1-\mathrm{C}$ (and -D) on a gas chromatogram.

osyl residues in $\alpha$-L-form. In a similar way, signals at 4.48 (and 4.45), 4.45 (and 4.50) and 4.52 (and 4.53) were respectively assigned to 3-O-, 6$O$ - and 3,6-di- $O$-substituted $\beta$-D-galactopyranosyl residues (Table 3). In the ${ }^{13} \mathrm{C}$-NMR spectrum, signals at 112.10 and $110.25 \mathrm{ppm}$ were assigned to anomeric carbons of terminal and 3-(and 5-) $O$-substituted $\alpha$-L-arabinofuranosyl residues, respective- 
ly. The signal at $106.60 \mathrm{ppm}$ was due to anomeric carbons of 3-O-, 6-O- and 3,6-di- $O$-substituted $\beta$ D-galactopyranosyl residues. The assignment of other signals is shown in Table 4. The results were consistent with those of other arabinogalactan (type II) and supported by methylation analysis.

\section{Carbohydrate-protein linkage analysis by re-} ductive alkaline degradation. ${ }^{16)}$

Cp-1-C (and -D) contained protein at 5.5\% (and $3.7 \%$ ). To learn the amino acid residue to which the carbohydrate was linked, the sample was subjected to reductive alkaline degradation followed by amino acid analysis. Five milligrams of Cp-1-C (and -D) in $0.25 \mathrm{M} \mathrm{NaOH}$ containing $0.5 \mathrm{M}$ $\mathrm{NaBH}_{4}(1.0 \mathrm{~mL})$ was kept at $45^{\circ} \mathrm{C}$ for $6 \mathrm{~h}$. The results of the amino acid analysis for the native and degradated proteins are listed in Table 5. In both samples, five kinds of amino acids (serine, proline, glutamic acid, glycine and alanine) were found to form about $74 \%$ of the total amino acid residues.

Table 3. ${ }^{1} \mathrm{H}-\mathrm{NMR}$ chemical shift of anomeric proton of Cp-1-C and Cp-1-D.

\begin{tabular}{llccc}
\hline \multicolumn{2}{c}{ Glycosidic linkage } & Cp-1-C & Cp-1-D & Ref. $^{a}$ \\
\hline \multirow{4}{*}{ Arabinose } & terminal & 5.27 & 5.26 & 5.23 \\
& 3- $O$-substituted & 5.10 & 5.09 & 5.07 \\
& 5- $O$-substituted & 5.27 & 5.26 & 5.23 \\
\hline \multirow{3}{*}{ Galactose } & 3- $O$-substituted & 4.50 & 4.48 & 4.48 \\
& 6- $O$-substituted & 4.45 & 4.45 & 4.46 \\
& 3,6-di- $O$-substituted & 4.53 & 4.52 & 4.52 \\
\hline
\end{tabular}

${ }^{a}$ Ref. 21).
Of these amino acids, serine and alanine, on reductive alkaline degradation, varied to a considerable degree in constitutional mole percentage. In the case of Cp-1-C, about 5 moles $(=27.20-21.91)$ of serine residue were lost and about 5 moles $(=$ 17.24-12.66) of alanine residue gained. In the case of Cp-1-D, these values were approximately 4 moles for each amino acid. The decrease in mole percentage of serine was almost equal to the increase in that of alanine in both samples, suggesting that the carbohydrate should link $O$-glycosidically to the serine residue of the protein. The data, moreover, indicate that about $20 \% \quad\left[\left(27.20^{-}\right.\right.$ 21.91)/27.20] of the serine residue is bound to carbohydrate in Cp-1-C. It is approximately $15 \%$ in Cp-1-D. It is interesting that almost half of the threonine residue $(55 \%=2.55 / 5.71)$ could also be a $O$-glycosidical junction between carbohydrate and protein in $\mathrm{Cp}-1-\mathrm{C}$, while having no relation in Cp-1-D. The concurrence of two kinds of carbohydrate-protein linkage in the molecule have been reported for AGP from the leaves of Acacia robust ${ }^{19)}$ and Cannabis sativa. ${ }^{14)}$ In both cases, serine and hydroxylproline were junctions between the carbohydrate and protein. A threonyl junction was proved for such AGP as one from the seed of radish, ${ }^{20}$ but the concurrence of serinyl and threonyl junctions in AGP have not yet been reported. AGP in Cp-1-C might be the first example for the concurrence of serinyl and threonyl junctions in a molecule.

Table 4. ${ }^{13} \mathrm{C}-\mathrm{NMR}$ chemical shift of Cp-1-C (and -D).

\begin{tabular}{ccccccc}
\hline \multirow{2}{*}{ Glycosidic linkage } & \multicolumn{7}{c}{ Chemical shifts (ppm) } \\
\cline { 2 - 7 } & C-1 & C-2 & C-3 & C-4 & C-5 & C-6 \\
\hline \multirow{2}{*}{$\alpha$-L-Araf } & & & & & \\
terminal & $112.10\left(110.9^{b}\right)$ & $84.8\left(83.0^{b}\right)$ & $79.4\left(78.2^{b}\right)$ & $86.7\left(85.5^{b}\right)$ & $65.7\left(62.9^{b}\right)$ & \\
3-linked & $110.25\left(109.3^{c}\right)$ & $84.2\left(81.0^{c}\right)$ & $84.8\left(85.1^{c}\right)$ & $84.2\left(84.1^{c}\right)$ & $64.1\left(62.4^{c}\right)$ & \\
5-linked & $110.25\left(108.5^{d}\right)$ & $84.2\left(81.8^{d}\right)$ & $79.4\left(77.2^{d}\right)$ & $84.2\left(83.2^{d}\right)$ & $72.3\left(67.9^{d}\right)$ \\
\hline$\beta$-D-Galp & & & & & & \\
3-linked & $106.6\left(105.3^{b}\right)$ & $72.7\left(71.6^{b}\right)$ & $84.2\left(81.8^{b}\right)$ & $71.4\left(70.1^{b}\right)$ & $79.4\left(76.8^{b}\right)$ & $64.1\left(62.7^{b}\right)$ \\
6-linked & $106.6\left(105.3^{b}\right)$ & $72.7\left(72.4^{b}\right)$ & $76.4\left(74.3^{b}\right)$ & $71.4\left(70.3^{b}\right)$ & $76.3\left(75.0^{b}\right)$ & $72.7\left(71.0^{b}\right)$ \\
3,6-linked & $106.6\left(104.8^{b}\right)$ & $72.7\left(71.6^{b}\right)$ & $86.7\left(81.8^{b}\right)$ & $71.4\left(70.1^{b}\right)$ & $76.3\left(75.0^{b}\right)$ & $72.7\left(71.0^{b}\right)$ \\
\hline
\end{tabular}

${ }^{*}$ Values in parentheses are published data $\left({ }^{b}\right.$ Ref. 21$),{ }^{c}$ Ref. 22), ${ }^{d}$ Ref. 23)). 
Table 5. Amino acid analysis of native and reductive alkaline degradated Cp-1-C and -D.

\begin{tabular}{lrrrr}
\hline Amino acid & Cp-1-C & Cp-1-C & Cp-1-D & Cp-1-D* \\
\hline Asp & 5.21 & 6.65 & 4.76 & 4.63 \\
Glu & 10.27 & 13.03 & 10.47 & 11.25 \\
Ser & 27.20 & 21.91 & 26.36 & 22.57 \\
Gly & 12.77 & 12.96 & 14.34 & 13.64 \\
Arg & 2.69 & 3.31 & 2.82 & 2.70 \\
Thr & 5.71 & 2.55 & 5.24 & 4.92 \\
Ala & 12.66 & 17.24 & 14.18 & 18.38 \\
Phe & 1.28 & 1.26 & 1.89 & 1.90 \\
Pro & 10.80 & 11.39 & 9.28 & 8.63 \\
Tyr & 0.20 & 0.37 & 0.29 & 0.19 \\
Val & 3.76 & 2.77 & 3.42 & 3.63 \\
Met & 0.58 & 0.52 & 0.40 & 0.68 \\
Lys & 0.78 & 0.51 & 0.96 & 0.89 \\
Ile & 3.38 & 2.79 & 3.41 & 3.55 \\
Leu & 2.69 & 2.41 & 2.18 & 2.44 \\
Total & 100.00 & 100.00 & 100.00 & 100.00 \\
\hline
\end{tabular}

${ }^{*}$ Reductive alkaline degradated sample.

\section{Molecular weight estimation.}

$\mathrm{Cp}-1-\mathrm{C}$ (and -D) was dissolved in $0.1 \mathrm{M} \mathrm{NH}_{4}$ $\mathrm{HCO}_{3}$ and the solution was subjected to HPLC. Dextran T-70 (mol. wt. 70,000), T-40 (43,500), T$20(20,400)$, and T-10 (10,500), products of Pharmacia Fine Chemicals, were used to calibrate molecular weight. The elution profile of $\mathrm{Cp}-1-\mathrm{C}$ (and -D) showed a single peak, and from its elution time, the molecular weight was determined to be 42,000 (and 23,000). This data is very close to the molecular weight reported for the type II AGP from the root of radish $(25,000)^{13)}$ (and turnip, 40,000). ${ }^{17)}$

For Type II AGP, some biological functions have been reported. ${ }^{12,14,16,21)}$ Although $\mathrm{Cp}-1-\mathrm{C}$ (and -D) was not examined for any biological functions, some medicinal actions of Lycium chinense fruit could be corroborated to some extent by the detection of two kinds of type II AGP in the fruit. The biological activity of the AGPs in Cp-1-C (and -D) as well as AGP-like compound(s) in Cp-2 presumed in a previous paper are now being studied.

\section{REFERENCES}

1) J. Liu and B. Cheng: Effect of lycium polysaccharide on immune responses of cancer patients following radiotherapy. Chin. J. Radiol. Med. Prot., 16, 18-20 (1996).

2 ) J. Liu, L. Zhang and Y. Qian: Immune tumor-inhibition of Lycium barbarum polysaccharide on S180bearing mice. Chin. J. Immunol., 12, 115-117 (1996).

3 ) B. Sheng and S. Zhang: Regulation to immune function of Lycium barbarum on old people above 60 years. Pharm. Clin. Med. Chin. Herbs, 4, 43-45 (1988).

4 ) Y. Liu, H. Zhou, X. Bai and J. Yin: The regulation of Lycium barbarum polysaccharide on apoptosis of mouse thymocytes in vitro. J. Beijing Med. Univ., 28, 111-133 (1996).

5 ) M. Tao and Z. Zhao: Research on response to genetic wounding of lycium in vitro. Chin. Herbs, 23, 474476 (1992).

6 ) S. Dharmananda: Lycium fruit for HIV/AIDS. Tradit. Med., 10, 23-24 (1995).

7 ) X. Qin, R. Yamauchi, K. Kato, K. Aizawa and T. Inakuma: Chemical features of water-soluble polysaccharides in Lycium chinense mill fruit. Res. Bull. Fac. Agric. Gifu Univ., 64, 83-88 (1999).

8 ) M. Dubois, K. A. Gilles, J. K. Hamilton, P. A. Rebers and F. Smith: Colorimetric method for determination of sugars and related substance. Anal. Chem., 28, 350356 (1956).

$9)$ Z. Dische: Methods in Carbohydrate Chemistry, R. L. Whistler and M. L. Wolfrom, eds., Academic Press, New York, p. 1488 (1962).

10) G. C. Millar: Protein determination for large number of samples. Anal. Chem., 31, 964 (1959).

11) A. B. Blakeney, P. J. Harris, R. J. Henry and B. A. Stone: A simple and rapid preparation of alditol acetates for monosaccharide analysis. Carbohydr. Res., 113, 291-299 (1983).

12) A. G. Alison and C. David: Structural analysis of the carbohydrate moiety of arabinogalactan-proteins from stigmas and styles of Nicotiana alata. Carbohydr. Res., 277, 67-85 (1995).

13) Y. Tsumuraya, K. Ogura, Y. Hashimoto, H. Mukoyama and S. Yamamoto: Arabinogalactan-proteins from primary and mature roots of radish (Raphanus sativus). Plant Physiol., 86, 155-160 (1988).

14) A. E. Clarke, R. L. Anderson and B. A. Stone: Form and function of arabinogalactans and arabinogalactanproteins. Phytochemistry, 18, 521-540 (1979).

15) N. Cartier, G. Chambat and J. P. Joseleau: An arabinogalactan-protein from the culture medium of Rubus fruticosus cells in suspension. Carbohydr. Res., 168, 275-283 (1987).

16) L. Saulnier and J. M. Brillouet: An arabinogalactanprotein from the pulp of grape berries. Carbohydr. Res., 188, 137-144 (1989).

17) K. Nakamura, Y. Tsumuraya, Y. Hashimoto and S. Yamamoto: Arabinogalactan-proteins react with eel anti-H agglutinin from leaves of cruciferous plants. 
Agric. Biol. Chem., 48, 753-760 (1984).

18) P. J. Harris, R. J. Henry, A. B. Blakeney and B. A. Stone: An improved procedure for the methylation analysis of oligosaccharides and polysaccaharides. Carbohydr. Res., 127, 59-73 (1984).

19) C. C. Shierlry and M. S. Alistair: Structural studies of an arabinogalactan-protein from the gum exudate of Acacia robusta. Carbohydr. Res., 133, 105-123 (1984).

20) Y. Tsumuraya and Y. Hashimoto: An L-arabino-Dgalactan and an L-arabino-D-galactan-containing proteoglycan from radish (Raphanus sativus) seeds. Carbohydr. Res., 161, 113-126 (1987).

21) M. Kreuger and G. J. Holst: Arabinogalactan proteins are essential in somatic embryogenesis of Daucus carota L. Planta, 189, 243-248 (1993).

(Received August 31, 1999; Accepted December 24, 1999)

$$
\begin{gathered}
\text { クコ果実のアラビノガラクタンープロテイン } \\
\text { について } \\
\text { 小秦 小明, 山内 亮, 相澤宏一1 } \\
\text { 稲熊隆博1, 加藤宏治 } \\
\text { 岐阜大学大学院連合農学研究科 } \\
\text { (501-1193 岐阜市柳戸 1-1) } \\
{ }^{1} \text { カゴメ総研 (329-2762 栃木県那須郡 } \\
\text { 西那須野町西富山 17) }
\end{gathered}
$$

クコの実からの冷水抽出物を DEAE-cellulose column chromatographyに供したところ，2 種類の arabinogalactan-protein (AGP) が得られた。一つは arabinose : galactose $=3: 1$ からなり，分子量は 42,000で, 糖は蛋白質の serine および threonine の 2 種のアミノ 酸残基とグリコシド結合している糖蛋白質であり，も う一つは arabinose: galactose $=1: 1$ からなり, 分子量 は23,000で，糖は蛋白質の serine 残基にグリコシド 結合している糖蛋白質であることが明らかになった。 さらに構造解析の結果, 両者はともに分岐した type I に属する arabinogalactan であるが，大きな相違点は (1 $\rightarrow 6)$ 結合が主に分岐として存在 (Cp-1-C) するか直 鎖として存在（Cp-1-D）するかの違いであることが 明らかとなった。 